\title{
Preservation of Freshness and Shelf Life Extension of Perishable Products (Meat and Fish) in Vacuum Packaging by Experimental Hydrostat
}

\author{
Anna V. Diachkova ${ }^{1 *}$, Natalya V. Tikhonova ${ }^{1}$ \\ 'Ural State University of Economics, Ekaterinburg, Russian Federation, *e-mail: a.v.diachkova@urfu.ru
}

Keywords:

meat preservation;

fish preservation;

safety factors

of perishable products

in vacuum package;

ultrahigh pressure;

hydrostat

\begin{abstract}
The article represents the results of meat and fish samples examinations, which are processed with high pressure.Processing with an experimental hydrostat in vacuum package of meat under the pressure $800 \mathrm{MPa}$ for 5 minutes, of fish under the pressure 600 and $800 \mathrm{MPa}$ for 300 seconds ensures the death of microorganisms, prevents protein cleavage, restrains oxidation processes of lipid components, significantly decreases the acid and peroxide values. It was established that the treatment of chilled carp with a pressure of 600 and $800 \mathrm{MPa}$ for 300 seconds provides high organoleptic characteristics of fish. The results obtained indicate that during storage of prototype carp, protein decomposition does not occur, therefore, processing of chilled fish with high pressure ensures the safety of the product. The acid and peroxide numbers of lipids in the samples of chilled carp in the control group were significantly higher than in the experimental groups. Processing chilled fish with high pressure ensures the death of microorganisms. So, vacuum packaging high helps to increase self-life perishable products.
\end{abstract}

\section{Сохранение свежести и продление срока годности скоропортящихся продуктов (мяса и рыбы) в вакуумной упаковке с помощью эксперименталыного гидростата}

\author{
А.В. Дьячкова ${ }^{1 *}$, Н.В. Тихонова \\ 'Уральский государственный экономический университет, г. Екатеринбург, Российская Федерация, *e-mail: a.v.diachkova@urfu.ru \\ Ключевые слова: \\ сохранение \\ свежести мяса; \\ сохранение \\ свежести рыбы; \\ показатели \\ безопасности \\ скоропортящихся \\ продуктов \\ в вакуумной упаковке; \\ В статье рассмотрены результаты исследований образцов мяса и рыбы, подвергнутых \\ обработке высоким давлением. Обработка экспериментальным гидростатом мяса в \\ вакуумной упаковке под давлением 800 МПа в течение 5 мин, рыбы - под давлением \\ 600 и 800 МПа в течение 300 с обеспечивает гибель микроорганизмов, предотвраща- \\ ет расщепление белка, сдерживает процессы окисления липидных компонентов, зна- \\ чительно снижает такие показатели, как кислотное и перекисное число. Установлено, \\ что воздействие давлением 600 и 800 Мпа на охлажденного карпа в течение 300 с \\ обеспечивает высокие органолептические показатели рыбы. Полученные результа- \\ ты свидетельствуют о том, что при хранении опытного образца карпа не происходит \\ разложение белка, и, следовательно, обработка охлажденной рыбы высоким давле-
}


сверхвысокое

давление;

гидростаm

\begin{abstract}
нием обеспечивает сохранность продукта. Кислотное и перекисное число липидов в образцах охлажденного карпа в контрольной группе значительно превышало аналогичные показатели в опытных группах. Вакуумная упаковка помогает существенно увеличить срок годности таких скоропортящихся продуктов, как мясо и рыба.
\end{abstract}

Для цитирования: Anna V. Diachkova, Natalya V. Tikhonova. Preservation of Freshness and Shelf Life Extension of Perishable Products (Meat and Fish) in Vacuum Packaging by Experimental Hydrostat Packaging by Experimental Hydrostat. Индустрия numaния/Food Industry. 2019. Vol. 4, No. 3. Pp. 22-33. DOI 10.29141/2500-1922-2019-4-3-3

\section{Introduction}

Nowadays the food industry develops efficient ways to preserve food in order to increase its shelf life. The main vector of the development of food technologies is the use of food additives prolonging the shelf life, and physical processing methods that inhibit the reproduction of bacterial cells.

Food spoilage can take place due to the oxidation of fat and the development of microflora. The bacteriological damage causes a loss of $25 \%$ of the total volume of perishable products annually. The main reason of the reduce of meat and fish products shelf life is the usage of unreasonable storage regimes that lead to enzymatic and microbial activity.

The effects of preservative factors (synthetic and biological preservatives, antibiotics, modified gas environment, ionizing and UV radiation, high hydrostatic pressure, etc.) on microorganisms that initiate the spoilage of fish are most effective at temperatures close to cryoscopic. The high pressure treatment of food products is widespread in the world, allows to inactivate microorganisms, the pathogens of various diseases and, in particular, L. monocytogenes, L. innocua, S. aureus, E. coli, etc. In this case, the efficiency of the treatment depends on a number of factors: processing duration, pressure, a type of microorganisms, water activity, chemical composition and $\mathrm{pH}$ of the treated environment.

Today, the considered technology is only applicable to inhibit the growth and reproduction of vegetative forms of bacteria, but the combination of pressure and temperature can also inactivate the spores of microorganisms. For example, the spores of Clostridium botulinum and some agents of the genera Bacillus and Clostridia can be inactivated through the synergistic effect of temperature and barometric factors. This kind of effect allows to reduce thermal effects due to the additional pressure applied to a system $[1 ; 2 ; 3]$. The resistance of spore forms is much higher than the vegetative forms, due to the presence of a serious protective mechanism in the former. So, it is known that for inactivation of yeast it is necessary to apply a pressure of 300-400 MPa at $25^{\circ} \mathrm{C}$ for a few minutes to the product, but to inactivate the yeast ascospores a higher pressure and a longer exposure are required. The spores of Clostridium botulinum are considered the most resistant among bacterial pathogenic spores, and the spores of Bacillus amyloliquefaciens among the non-pathogenic [1].

The microbial activity leads to the change in organoleptic and other quality indicators. In particular, the effect of deaminase enzyme on some free amino acids leads to the formation of ammonia odor; reduction of trimethylamine oxide (TMAO) with TMAO-demethylase leads to the formation of trimethylamine, which causes the characteristic smell of deterioration; under the influence of bacterial decarboxylases on lysine, tyrosine, arginine and phenylalanine, biogenic amines (cadaverine, tyramine, phenylethylamine) are formed, leading to a decrease in qualitative characteristics; the products of life activity of microorganisms are low-molecular acids (formic and acetic), which deteriorate the organoleptic characteristics of food.

A pressure of more than $200 \mathrm{MPa}$ at a temperature not higher than $45^{\circ} \mathrm{C}$ can effectively inactivate the vegetative forms of almost all pathogenic and spoilage-causing microorganisms without affecting the flavor characteristics [4]. Application of a mild high-pressure treatment $(200,300$, and $400 \mathrm{MPa}$, $5 \mathrm{~min}$ each) and films activated with a mixture of thymol plus the bacteriocin enterocin AS-48 allow to reduce of the initial microbial load in sea bream fillets and retardation of its growth during refrigerated storage [5].

However, it is important to note that the efficiency of the process depends on the type and complexity of the organization of microorganisms, the chemical composition and $\mathrm{pH}$ of the treated environment, as well as on the activity of water. Gram-negative bacteria are more sensitive to the effects of high pressure than gram-positive ones. Barometric effects cause destruction of cell membranes and intracellular proteins, which play the most important role in the life activity of microorganisms, and that leads to degradation of cellular structures and the ultimate destruction of the cell as a whole. A pH shift to an acidic environment and an increase in pressure have a synergistic effect when eliminating microorganisms. Due to the increase in the acidity 
of the environment, the activity of water molecules is inhibited, which contributes to a significant slowdown of the inactivation processes, induced by ultrahigh pressure $[6 ; 7 ; 8]$.

In the course of multiple studies, it was proved that the exposure of meat and meat products to a pressure of $600 \mathrm{MPa}$ at $20^{\circ} \mathrm{C}$ for 180 seconds can eliminate the causative agents of listeriosis (Listeriamonocytogenes) and inhibit other life-threatening microorganisms: E. coli, Salmonella, Vibrio, most types of mold fungi and pathogenic bacteria with little effect on taste, flavor, texture, appearance and nutritional value of food $[7 ; 9 ; 10 ; 11]$.

Nevertheless, Olatunde and Benjakul note negative effect of high-pressure treatment on organoleptic characteristics of fish [12]. Enzyme structure and function can be affected by high-pressure. It gives fish products a cooked appearance at high pressure (>200 MPa). High pressure can induce the formation of formaldehyde, which induces protein crosslinking, thus causing an increase in the hardiness of the treated fish. During processing, the organoleptic characteristic of HHP-treated food can be changed. In addition, HPP can accelerate lipid oxidation of treated seafoods during storage.

To deactivate the yeast, it is necessary to apply a pressure of about $300-400 \mathrm{MPa}$ at $25^{\circ} \mathrm{C}$ for a few minutes to the product; however, to destroy the yeast ascospores higher pressure and longer exposure are required [13].

Jung, Ghoul and co-authors report that there is a delay for a week in the growth of microorganisms in the beef meat processed under pressure (130-520 $\mathrm{MPa}$ for $4.3 \mathrm{~min})$. The treatment with pressure of $130 \mathrm{MPa}$ improves the color of meat, the achieved effect continues for 3 days at a storage temperature of $+4{ }^{\circ} \mathrm{C}[14]$.

As the result of their studies Han and Ledward found that with an increase in beef treatment pressure from 200 to $800 \mathrm{MPa}$ (at a constant temperature from 20 to $40^{\circ} \mathrm{C}$ ) the stiffness of muscle tissue rises, but significantly decreases with the use of pressure of $200 \mathrm{MPa}$ (at a temperature of 60 and $70{ }^{\circ} \mathrm{C}$ ) [15]. Bai and co-authors showed that after exposure to high pressure (300-700 $\mathrm{MPa}$ ) for 20 minutes, significant changes in organoleptic parameters of meat are observed. Furthermore, the modifications are spotted in the microstructure of cattle and lamb muscle tissue [16].

Qin and others established that through the preservation of meat (beef) the activity of tissue enzymes - calpains - decreases, and the activity of acidic and alkaline phosphatases is not significantly different from the values in the control samples. A pressure of about 100-200 MPa can inactivate calpastatin (an inhibitor of calpain activity) faster than calpain itself (an enzyme) [17].
An assessment of the population dynamics of pathogenic organisms of chicken fillet in a vacuum package, treated with high pressure (500 MPa / 10 min) at storage temperatures of 4 and $12^{\circ} \mathrm{C}$, can be determined by sensory analysis. During the whole period of shelf-life of the samples, the population of pathogens remained below or around the detection limit of the counting method at both temperatures [18].

It should be noted, that toxins can cause poisoning in a person who consumes stale meat products. So, Shiga toxin-producing Escherichia coli O157: $\mathrm{H} 7$ (STEC) is a common contaminant in meat. Huang, Shiowshuh Sheen, Sommers et al proved efficiency of HHP for destroyed Escherichia coli and STEC in chicken meet by treatment 250-350 MPa (temperature from -15 to $-4^{\circ} \mathrm{C}$, time $10-20 \mathrm{~min}$ ) [19]. The use of high-pressure treatment contributes to the reduction of Listeria innocua contamination in vacuum-packaged dry-cured pork products [20].

In the study of fish high pressure treatment, Jung and co-authors conclude that in the muscle tissue of fish, treated with pressure of 130-520 MPa for 4.3 minutes, there is a delay in the growth of microorganisms for a week [14]. The results of the studies are known which indicate that processing fish and seafood with pressure of 200 and $400 \mathrm{MPa}$ can prolong its shelf-life compared with the traditional shelf-life (7 days).

At the same time, further vacuum packaging of the processed product is necessary [4].

The shelf life of protein products (meat and fish) during refrigerated storage (temperature $+4{ }^{\circ} \mathrm{C}$ ) depends on various and interrelated factors, in particular, on the microbial load and activation of lipid oxidation processes. But the main determinant of the shelf-life of products is a microbial factor. Different types of packaging are used as protection from microbial contamination: MAP (modified atmosphere packaging) - packaging with high and low oxygen content, CAP (controlled atmosphere packaging) - vacuum packaging.

It should be noted, that the use of MAP-packaging has certain negative consequences for the quality of the product, in particular, the enhancement of lipid oxidation processes, causing the presence of undesirable after-tastes. Color changes occur as a result of the oxidation of phospholipids of cell membranes $[21 ; 22 ; 23]$.

From the foregoing it follows that MAP-package does not ensure the safety of the product. The solution to this issue can be a fundamentally new method of storage in a vacuum package, consisting in the use of high-pressure processing technology, which ensures the inactivation of all microorganisms both on the surface and inside the muscle tissue. The use of high pressure in the processing of food raw ma- 
terials and food products along with a bactericidal effect has other positive aspects, in particular, does not reduce the nutritional and biological value [6].

It is necessary to take into account that preservation with the use of high temperatures can have a negative impact on the quality and consumer properties of food products due to the destruction of micronutrients [24]. The foregoing relates in a large extent to perishable food products, in particular, to meat products and fish.

This means that the search for optimal criteria for pressure and the duration of exposure during the high-pressure treatment of specific types of food is necessary. The contradiction between the need to study the physical methods of food processing (meat and fish) in terms of their impact on shelf-life and microbiological characteristics of the product, and the insufficient scientific and practical development of this issue has determined the goal of our research.

The development of alternative, innovative methods of preservation and storage of food raw materials and food products, which would provide regulated quality and safety indicators, is becoming relevant.

In this regard, the aim of the research is to develop a method for increasing the shelf-life of perishable food products, using the samples of chilled meat and fish in vacuum packaging and an experimental hydrostat.

\section{Materials and Methods}

Experimental work included two areas of research with different samples for analysis (Table 1).

Block 1: the study of chilled fish. As the study objects were taken the samples of common carp (Сyprinuscarpio) cooled, whole, IV quartal, and rainbow trout (Salmoirideus) cooled, gutted, with head, IV quartal.
Three groups were formed for the experiment. The first group (control) - the samples of chilled carp, packaged in a vacuum package - was not pressure treated. Before processing, the fish samples were placed in a vacuum package using a HENKELMAN vacuum packer of the BOXER series. The samples of the second group were treated with pressure of $600 \mathrm{MPa}$ for $(300 \pm 10)$ seconds, the samples of the third group were treated with pressure of $800 \mathrm{MPa}$ for $(300 \pm 10)$ seconds.

Since, in accordance with regulatory requirements, the shelf-life of whole fish in quarter IV at a storage temperature of 0 to $+2{ }^{\circ} \mathrm{C}$ is no more than 12 days, and a vacuum package can increase the shelf life of the product by 1.5 to 20 days, the quality assessment of chilled fish in this experiment was taken after $0 ; 10 ; 15 ; 20$ and 30 days.

Block 2: an experiment with 5 beef samples in control and experimental groups. The meat was kept at a temperature of $+4^{\circ} \mathrm{C}$.

Before processing, all samples were placed in a vacuum package using a HENKELMAN vacuum packer of the BOXER series. The used packing material has the necessary elasticity, which makes it possible to transmit pressure without structural damage to the samples. In addition, vacuum packaging has a reversible deformation and is ideal when using high pressure: such a packaging can be compressed without significant structural damage to the product itself, since it can return to its original shape after decompression.

Pressure treatment was carried out using an experimental unit - hydrostat (Fig. 1), which has the following technical characteristics: working pressure $-800 \mathrm{MPa}$, maximum pressure - $1200 \mathrm{MPa}$, time to reach the mode is $2-3$ minutes, working fluid - a mixture of industrial oil and glycerin.

The studies were carried out in a laboratory facility at the Research Institute of Metal Physics of

Table 1. Objects of research for an experiment

Таблица 1. Объекты исследования

\begin{tabular}{|c|c|c|c|c|c|}
\hline & \multirow{2}{*}{$\begin{array}{c}\text { Samples of food protein } \\
\text { product }\end{array}$} & \multirow{2}{*}{$\begin{array}{l}\text { Samples } \\
\text { weight, } \mathrm{g}\end{array}$} & \multirow{2}{*}{$\begin{array}{l}\text { Control group } \\
\qquad(n=5)\end{array}$} & \multicolumn{2}{|c|}{ Experimental groups } \\
\hline & & & & 2 experimental group & 3 experimental group \\
\hline $\begin{array}{l}\overline{\check{u}} \\
\frac{\bar{O}}{\infty}\end{array}$ & $\begin{array}{l}\text { Common carp } \\
\text { (Cyprinuscarpio) } \\
\text { Rainbow trout } \\
\text { (Salmoirideus) }\end{array}$ & $840-1020$ & $\begin{array}{l}\text { Samples of chilled } \\
\text { carp nontreated } \\
\text { with pressure, } \\
\text { vacuum packaged }\end{array}$ & $\begin{array}{l}\text { Samples treated with } \\
\text { pressure of } 600 \mathrm{MPa} \text { for } \\
\text { (300 } \pm 10) \text { seconds }(n=5) \\
\text { Temperature during high- } \\
\text { pressure process }+18{ }^{\circ} \mathrm{C}\end{array}$ & $\begin{array}{l}\text { Samples treated with } \\
\text { pressure of } 800 \mathrm{MPa} \text { for } \\
\text { (300 } \pm 10) \text { seconds }(n=5) \\
\text { Temperature during high- } \\
\text { pressure process }+18{ }^{\circ} \mathrm{C}\end{array}$ \\
\hline 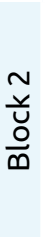 & $\begin{array}{l}\text { Beef meat from a shoulder } \\
\text { of the carcass } 48 \text { hours } \\
\text { after slaughter of cattle } \\
\text { (yearling bulls of black- } \\
\text { and-white breed, } \\
18 \text { months old }\end{array}$ & $520-630$ & $\begin{array}{l}\text { Samples of chilled } \\
\text { meat nontreated } \\
\text { with pressure, } \\
\text { vacuum packaged }\end{array}$ & \multicolumn{2}{|c|}{$\begin{array}{l}\text { Samples of chilled meat treated with pressure } \\
\text { of } 800 \mathrm{MPa} \text { for }(300 \pm 10) \text { seconds }(n=5) \\
\text { Temperature during high-pressure process }+18^{\circ} \mathrm{C}\end{array}$} \\
\hline
\end{tabular}




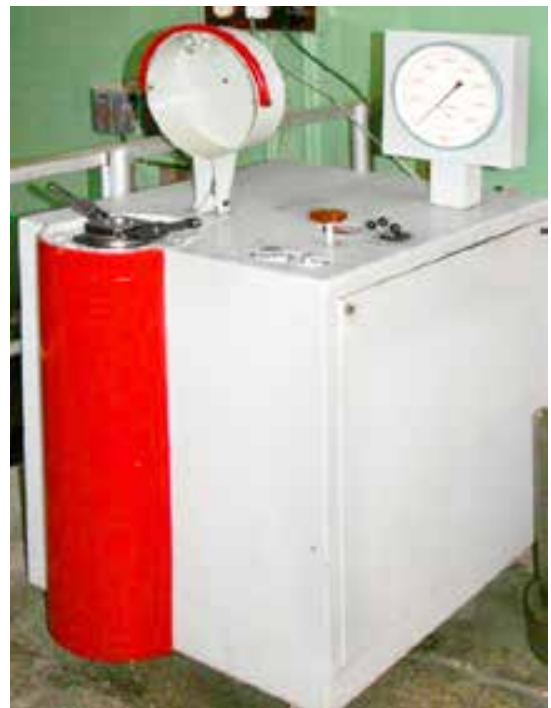

Fig. 1. High pressure installation (hydrostat) Puc. 1. Anпарат высокого давления (гидростат)

the Ural Branch of the Russian Academy of Sciences (Ekaterinburg) and at the Department of Food Engineering, Physics and Chemistry of the USUE (Ekaterinburg).

To define the freshness of the fish in the process of conservation there were used organoleptic, physical-chemical and microbiologic markers. The colour and condition of the fish was defined by visual examination. The body of the fish was also examined by the squeezing of fingers.

The content of protein and fat were done by the way of spectroscopy in the nearest infrared part with the help of analyzer "FoodScan». Finding of the amino-ammoniacal nitrogen (AAA) was made by the titrimetry by the sodium hydrate mixture and then was calculated by the formula. The acid index of fat was done by the titrimetry based on titrimetry of free fatty acids by the hydroxide with phenolphthalein as well until the light-pinkish tinge, which was permanent for about 30 seconds, appeared. The core sense of that method is laid in saponifying by the $\mathrm{KOH}$ and neutralization of all fatty acids, which are situated in dose by weight. The peroxide value was defined by the titrimetry, based on the impact of potassium iodide in the algid vinegar acid mixture and isooctene on the oxidation product of fat with the following determination of the oozed out iodine during the titrimetry by the sodium thiosulfate mixture until the blueish tinge disappear.

To define QMAFAnM (Quantity of Mesophilic Aerobic and Facultative Anaerobic Microorganisms) there was a dilution of fish and meat pieces prepared with the help of distilled aseptic water with the rain 1:10, that dilution was made 10 times, then from the last two dilutions $1 \mathrm{ml}$ of diluted material was placed in the Petri dishes and everything was poured with melted and chilled agar, then it was incubated in the thermostat under the temperature $30-32{ }^{\circ} \mathrm{C}$ for 72 hours and the amount of microgerms was calculated as well. The Coliform bacterias was defined by the inoculation in the Kessler medium, then incubated in the thermostat under the temperature $37^{\circ} \mathrm{C}$ for 24 hours, after the inoculation in the Endo medium was made, incubated in the thermostat and visually defined the presence of red colonies with red glitter and without it and the pink colonies. S. Aueres were defined by the inoculation of the 10 times diluted average sample on the fish peptonic broth, incubation in the thermostat and inoculation on the egg yolk high salt agar culture medium, thermostating and defining the colonies with iridescent wreath, if such exist.

The assessment of the outer quality and the colour of meat were conducted with the help of visual examination of the surface of the whole fish and the surface of cutoff. The body of the meat was defined with the help of pressing. The transparency and scent of the meat broth was defined by the way of boiling. VFA (volatile fatty acid) in the meat was defined by distilling off and the following titrimetry of distillate by the $\mathrm{KOH}$ and calculated by the formula. The determination of oxidation retarder was conducted with the help of potentiometric method.

Statistical processing of the results was performed using standard computer programs Microsoft Excel XP, Statistica 8.0. Confidence level -0.95 $(p \leq 0.05)$.

\section{Results}

The high-pressure food processing technology consists in the following: experimental samples are placed in a high-pressure chamber in a vacuum package, the chamber is filled with working fluid to the full and hermetically closed, set the required pressure and treated for selected time periods, then fish samples are stored at a temperature of from 0 to $-2{ }^{\circ} \mathrm{C}$, meat samples: from 0 to $4{ }^{\circ} \mathrm{C}$.

As a result of the research, it was established that the treatment of chilled carp with pressure of 600 and $800 \mathrm{MPa}$ for 300 seconds ensures high organoleptic characteristics of fish. After 30 days, the experimental samples of carp had a clean surface of natural coloration, dense consistency of muscle tissue and the smell of fresh fish. The increase in pressure from 600 to $800 \mathrm{MPa}$ did not adversely affect the organoleptic indicators of chilled fish. At the same time, the control samples of chilled carp after 20 days of storage did not meet the requirements for a fresh product according to their organoleptic characteristics. So, after 20 days of storage, the control fish samples had an unpleasant smell, a dull surface covered with muddy mucus, the gills were noted for a dark color. 
Thus, the processing of chilled carp with pressure of 600 and $800 \mathrm{MPa}$ for 300 seconds allows preserving the organoleptic characteristics of fish for 30 days of cold storage, by preventing enzymatic decomposition and microbiological spoilage.

It is known that proteins of the actinomyosin complex and collagen determine the consistency of fish muscle fibers. The enzymes of proteolytic microorganisms, through the decomposition of muscle protein, reduce trimethylamine $\mathrm{N}$-oxide to trimethylamine, dimethylanine and ammonia. When protein is decomposed in muscles, a number of substances are formed, such as monoethylamine, hydrogen sulfide, indole, formic and acetic acids, etc. Fish poisons, which are formed by utilizing fish that have undergone the bacterial decomposition, are of the major impact in cases of non-specific fish poisoning. As a result of the protein breakdown under the effect of Proteus, Escherichia, Achromabacter and others, histidine is formed, which can be decarboxylated to histamine, causing intoxication. In this regard, the determination of the amount of protein and its decay products during storage of fish is an important indicator of its freshness and an in- direct indicator of microbiological spoilage. Figure 2 shows the kinetics of protein degradation of the control and the HPP treated samples of chilled carp muscle tissue.

From fig. 2 it follows that during storage of control samples of carp, a significant decrease $(p<$ 0.05 ) of the protein level after 30 days of refrigerated storage by $15.4 \%$, which indicates the process of protein breakdown and deterioration in the quality of the food product. The amount of protein in the control group of chilled carp after 10; 20 and 30 days of storage is $16.8 ; 15.1$ and $14.2 \%$, respectively, while in the second experimental group - $16.5 ; 16.4$ and $16.4 \%$, in the third group - $16.7 ; 16.7$ and $16.5 \%$.

One of the indicators of protein breakdown is the presence of amino-ammonia nitrogen (AAA), which is formed as a result of the bacterial deaminase effect on certain free amino acids. The content of AAA during the process of cold storage in the control and experimental samples of cooled carp treated with high pressure is presented in Fig. 3.

The amount of AAA after 30 days of storage of chilled carp in the control group is $85 \mathrm{mg} / 100 \mathrm{~g}$, in

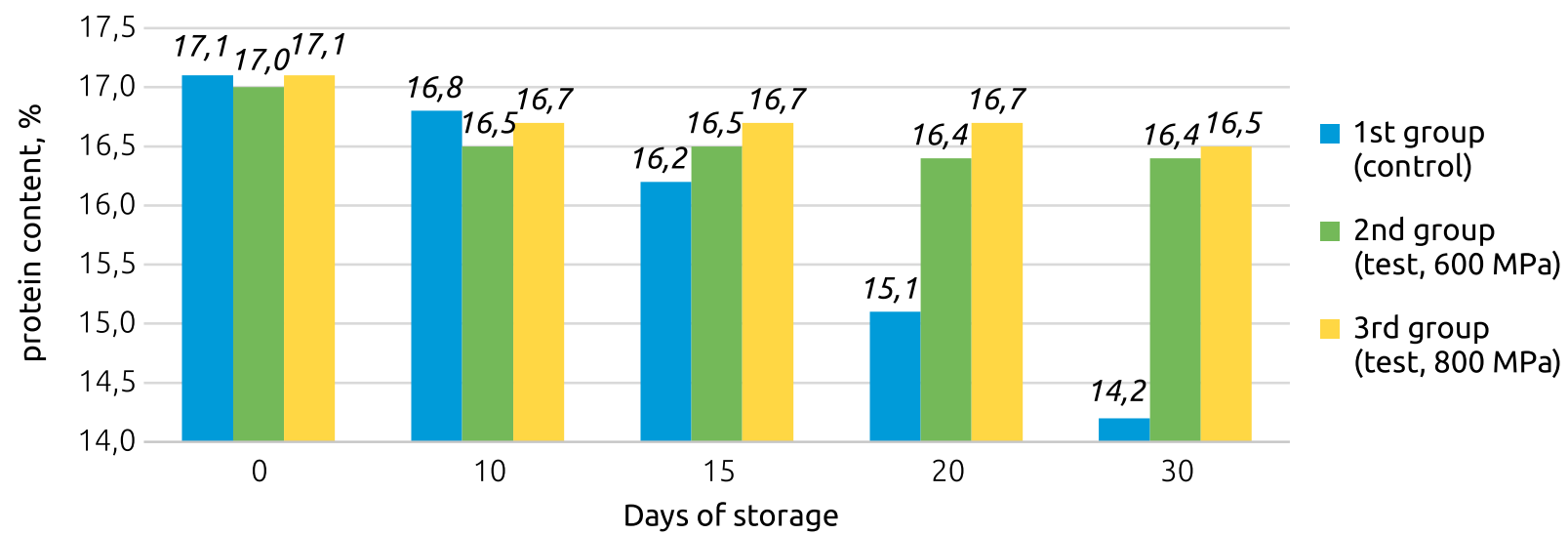

Fig. 2. Protein content in chilled carp muscle tissue in vacuum packaging, high pressure treated

Puс. 2. Содержание белка в филе охлажденного карпа в ваккумной упаковке и обработанного высоким давлением

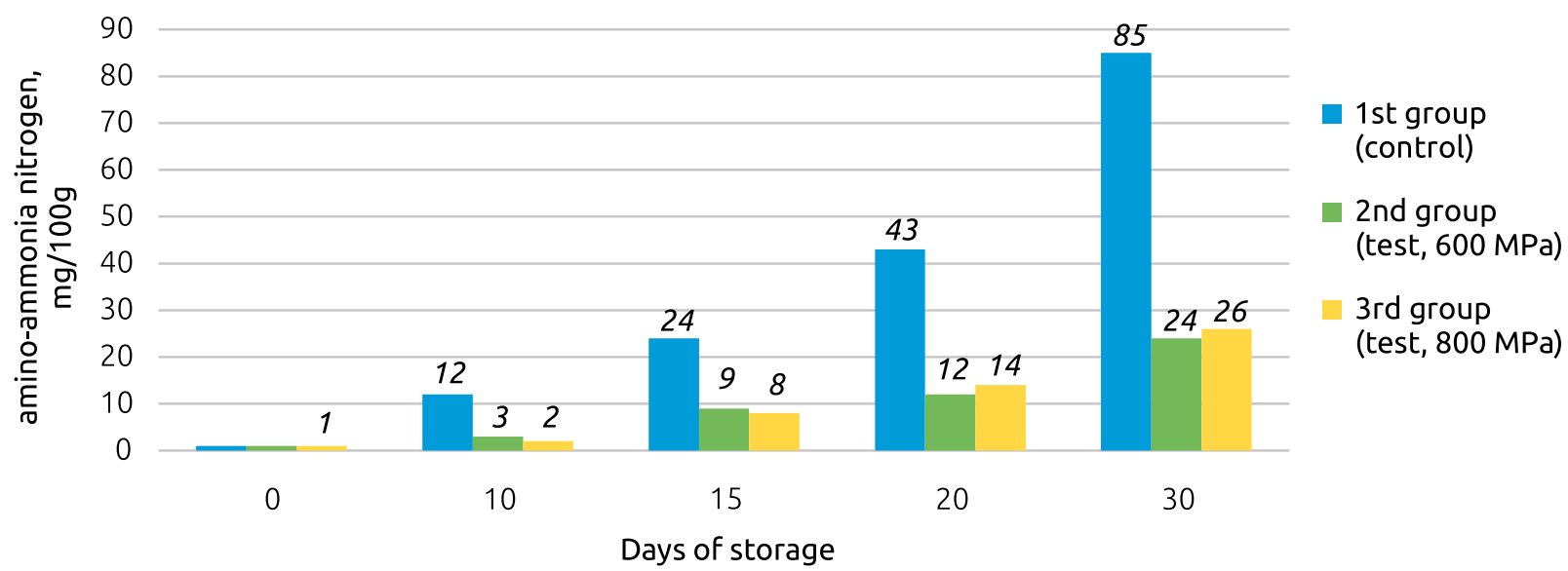

Fig. 3. AAA content in chilled carp muscle tissue in vacuum packaging, pressure treated

Puc. 3. Содержание AAA в филе охлажденного карпа в ваккумной упаковке и обработанного высоким давлением 
the carp samples of the second and third experimental group - 24 and $26 \mathrm{mg} / 100 \mathrm{~g}$, which is lower than the control by 71.8 and $69.4 \%$, respectively. The obtained results indicate that during storage of the experimental samples, protein breakdown does not occur, meaning that the processing of chilled fish with high pressure ensures safety of a product, which is consistent with the assessment of organoleptic characteristics.

In fact, the ultrahigh pressure treatment of highfat products may initiate oxidative spoilage processes. Therefore, the assessment of fish fat quality indicators - the acid and peroxide numbers - is important in the study of chilled fish processed with high pressure.

Figures 4 and 5 show the dynamics of the acid and peroxide numbers of lipids in the control and experimental samples of chilled carp in a vacuum package processed with high pressure.

It follows from the figures that the acid and peroxide numbers of lipids in the samples of chilled carp in the control group were significantly higher than in the experimental groups, and after 15; 20 and 30 days of storage were equal to $2.4 ; 4.1$ and $8.9 \mathrm{mg} \mathrm{KOH} / \mathrm{g}$ and $4.5 ; 6.8$ and $9.5 \mathrm{mmol}$ of active oxygen $/ \mathrm{kg}$, respectively.

At the same time, in the carp samples of the second group the acid number after 15; 20 and 30 days of storage was measured as $1.5 ; 2.8$ and $3.6 \mathrm{mg} \mathrm{KOH} / \mathrm{g}$, respectively, which is lower than the control by 37.5 ; 31.7 and $59.5 \%$. Similar results were obtained in the carp samples of the third experimental group. There the acid number of lipids after 15; 20 and 30 days of storage was at $1.9 ; 3.2$ and $4.1 \mathrm{mg} \mathrm{KOH} / \mathrm{g}$, which is lower than the control by $20.8 ; 22.0$ and $53.9 \%$.

The peroxide number of lipids in carp samples of the second and third experimental groups is 49.5 and $40.0 \%$ lower than the control. The data obtained indicate that the high-pressure treatment of chilled fish inhibits the processes of lipid peroxidation and hence increases its shelf-life. At the same time, an increase in pressure during the processing of chilled fish from 600 to 800 MPa considerably increases the acid and peroxide numbers: in the third group, after 30 days of fish storage, the acid and peroxide values of lipids are 13.8 and $18.6 \%$ ( $p$ $\leq 0.05$ ) higher, which suggests that the pressure of $600 \mathrm{MPa}$ for processing fish is efficient.

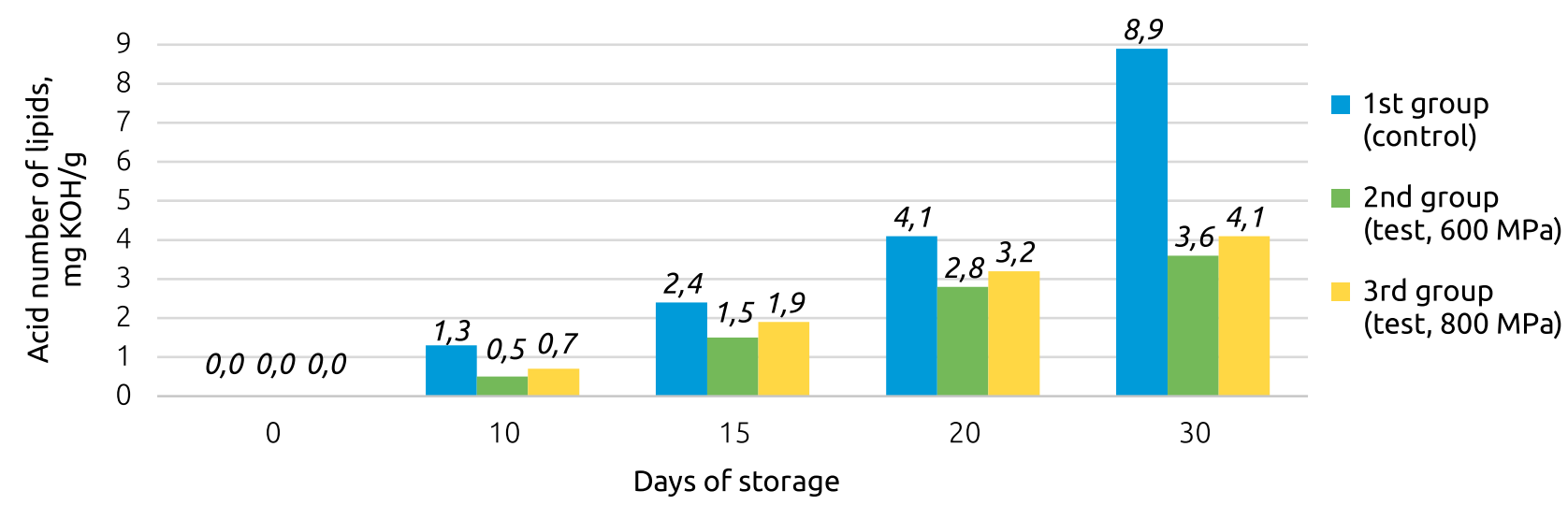

Fig. 4. Acid number of lipids of carp cooled in a vacuum package, treated with pressure

Puc. 4. Оксидное число липидов охлажденного карпа в ваккумной упаковке и обработанного высоким давлением

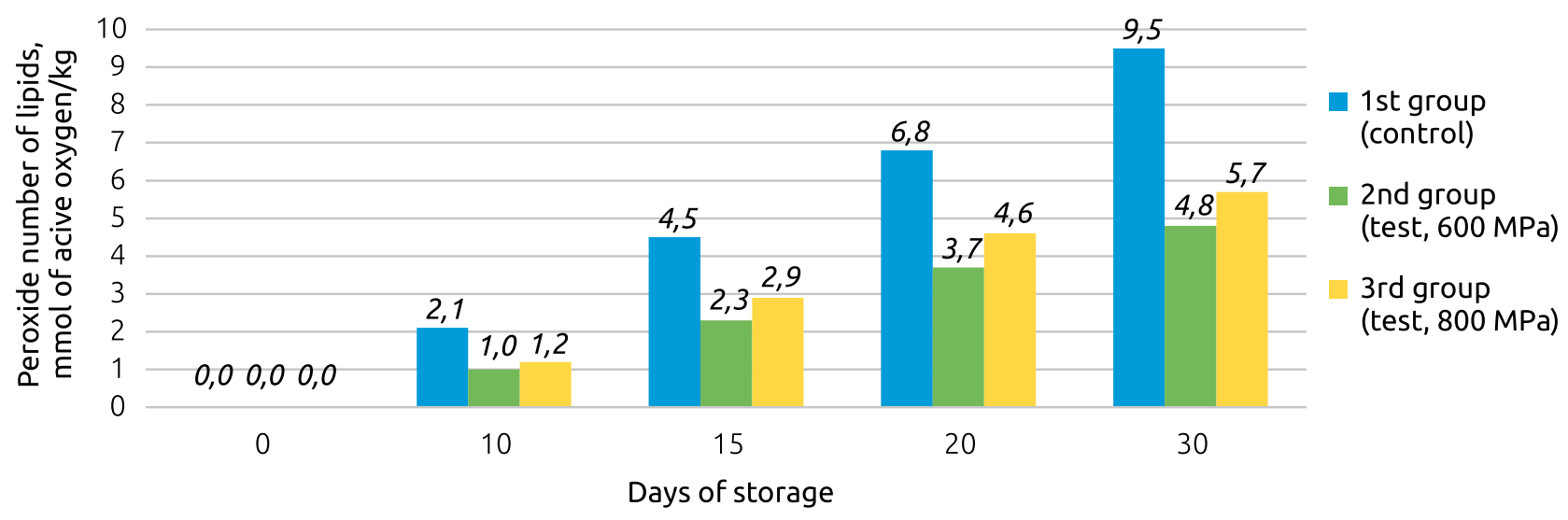

Fig. 5. Peroxide number of lipids of carp cooled in a vacuum package, pressure treated Puс. 5. Пероксидное число липидов охлажденного карпа в ваккумной упаковке и обработанного высоким давлением 
The treatment of chilled fish with high pressure ensures the bacterial destruction: mesophilic aerobic and facultative anaerobic microorganisms were not detected in carp samples processed under high pressure, whereas control samples after 20 days of storage did not meet the hygienic requirements. It should be noted that in the control samples of the fish muscle tissue and skin, bacteria of the genus Achromobacter and Pseudomonas were detected throughout the entire period, the proportion of bacteria of the genus Pseudomonas was $87 \%$ of the total number of bacteria detected.

Thus, according to the microbiological indicators of chilled carp in vacuum packaging, it was established that the treatment with pressure of 600 and $800 \mathrm{MPa}$ for 300 seconds increases the shelf life of the product by 1.5 times (from 15 to 20 days), which is consistent with the results of organoleptic estimation and the nutritional value of fish. Treatment with pressure of $600 \mathrm{MPa}$ is proven to be the most effective.

The study of meat freshness indicators was conducted after 5,7 , and 10 days of storage for semi-finished meat with an estimated shelf-life of 5-7 days in accordance with sanitary norms.

After 10 days of storage all the samples of meat of the first (control) and second groups were fresh considering the organoleptic parameters (Table 2 ).

It should be noted that in the control samples of the fish muscle tissue and skin, bacteria of the genus Achromobacter and Pseudomonas were detected throughout the entire period, the proportion of bacteria of the genus Pseudomonas was $87 \%$ of the total number of bacteria detected.

So, the quantity of mesophilic aerobic and facultative anaerobic microorganisms (QMAFAnM) in samples of meat of the experimental group was at the level of $1.2 \times 10 \mathrm{CFU} / \mathrm{g}$ (the norm for vacuum-packed meat is no more than $1.0 \times 104$ CFU/g), while QMAFAnM in samples of meat of the first (control) group - 2,7×102 CFU/g.

In the control and experimental samples of meat, the acid number and peroxide numbers after 10 days of storage did not exceed the norm for fresh fat. After 10 days of storage the acid and peroxide numbers in samples of fat exuded from meat were equal to $0.6 \mathrm{mg} \mathrm{KOH} / \mathrm{g}$ (the norm is no more than $4.0 \mathrm{mg} \mathrm{KOH} / \mathrm{g}$ ) and $1.1 \mathrm{mmol}$ of active oxygen $/ \mathrm{kg}$ (the norm is no more than $10.0 \mathrm{mmol}$ of active oxygen $/ \mathrm{kg}$ ), respectively. Similar results were obtained when studying the processes of lipid peroxidation in the samples of the second group. After 10 days of storage, the acid number amounted to $0.4 \mathrm{mg}$ $\mathrm{KOH} / \mathrm{g}$, peroxide number was $0.9 \mathrm{mmol}$ of active oxygen/kg.

The results of the peroxide value are consistent with the assessment of the antioxidant activity of meat (AOA). It was established that the experimental samples of meat had a higher AOA (0.35 \pm 0.02 mole equiv. $\left./ \mathrm{dm}^{3}\right)$, which is $66.7 \%$ highly significant $(P \leq 0.01)$ and higher than the AOA of control samples $\left(0.21 \pm 0.05\right.$ mole equiv. $\left./ \mathrm{dm}^{3}\right)$.

As it is known, in biological systems there is a mobile equilibrium between the generation of oxidants (OA), which include hydrogen peroxide, organic hydroperoxides, nitrous oxide, superoxide radical, hydroxyl radical, etc., and the activity of the cell antioxidant defense system consisting of non-enzymatic and enzyme antioxidants. The shift in the AOA/OA equilibrium due to factors can either cause an increase in OA and a decrease in AOA (oxidative stress), or vice versa. In our case, the effect of high pressure on the cells of the meat led to a shift in the AOA/OA equilibrium towards an increase in AOA, associated with a significant decrease (even complete disappearance) of reactive oxygen species and a significant decrease in the rate of their generation over time compared to the meat in the control group. In

Table 2. Organoleptic indicators of freshness of control and experimental meat samples after 10 days of storage Таблица 2. Органолептические показатели свежести контрольного и экспериментального образцов после 10 дней хранения

Indicator name

Appearance and color

Muscles on the cut

Consistency

Flavor

Condition of fat

Broth flavor

Broth transparency
Control group

Experimental group

Moistened in places; dark-red color

Wet, leaving a wet spot on absorbent paper, slightly sticky, dark-red color

Less dense and less elastic on the cut; a dimple after pressing with a finger levelled off slowly

Slightly sour

Has dull grayish tint, slightly sticks to fingers

With a smell, not inherent to a fresh broth

Slightly turbid
Has a crust of drying up; pale red color

Slightly wet, leaving no wet spots on absorbent paper

Elastic, dense, a dimple after pressing with a finger levelled off quickly

Specific, inherent to beef

Yellow-tinted, hard consistency, crumbles when squeezed

Aromatic

Transparent 
addition, high AOA values stem from an increase in sulfhydryl groups in the treated meat due to their release from the polymerized myofibrils proteins after the application of high pressure. As known, $\mathrm{SH}$ groups have a reducing ability, giving the "antioxidant" properties to the compounds. The thiol-type antioxidant group includes proteins with SH-groups, in particular albumin, low-molecular-weight thiols, glutathione, cysteine, homocysteine, etc. Perhaps, an increase in AOA of meat from the experimental group is associated with the formation of cysteine produced from cystine under pressure. At the same time, the disulfide group of cystine is converted into the $\mathrm{SH}$ group, which is capable of being involved in the enzymatic reduction of the oxidation products of phenolic antioxidants, in particular vitamin $\mathrm{E}$, and thereby to increase the AOA of the processed meat.

The nutritional value of meat, in the first place, is determined by the content of biologically complete proteins. The determination of the nutritional value at the expiration of the studied storage period shows that in the experimental samples of meat, by the end of the storage period, the amount of protein decreased by $1.5 \%$, while in the control samples by $3.1 \%$. A decrease in the fat content in the experimental and control samples was $1.7 \%$ and $4.3 \%$, respectively. The results are attributed to the destruction of ester bonds in triglycerides with the participation of water, and that is accompanied by the accumulation of free fatty acids. This process is catalyzed by both tissue lipases and the lipolytic enzymes of microorganisms, which retain their viability in products not treated with high pressure.

The preservation of meat proteins and lipid components is evidenced by the results of determination of amino-ammonia nitrogen and volatile fatty acids (VFA). It was established that the content of amino-ammonia nitrogen in the control samples of meat after 5,7 , and 10 days is $0.73 ; 1.85$; and 2.43 $\mathrm{mg} / 10 \mathrm{~cm}^{3}$, in experimental samples - $0.12 ; 0.16$; $0.24 \mathrm{mg} / 10 \mathrm{~cm}^{3}$ at a rate for fresh meat - less than $1.26 \mathrm{mg} / 10 \mathrm{~cm}^{3}$. The amount of VFA in control samples of beef after 5,7 and 10 days of storage is at the level of $0.4 ; 2.2$ and $3.1 \mathrm{mg}$ alkali/g, in test samples $-0.2 ; 1.0 ; 2.3 \mathrm{mg}$ alkali/g (with the norm of up to $4 \mathrm{mg}$ alkali/g). So, obtained data showed high safety of meat HHP treated.

\section{Discussion}

Thus, as a result of the research, it was established that the freshness of fish and microbiological safety indicators, the shelf life and storage mode of chilled fish were determined: treated with high pressure - no more than 30 days at a storage temperature from 0 to $-2{ }^{\circ} \mathrm{C}$, which is consistent with the results of research $[7 ; 13]$. The positive effect was established of processing chilled common carp in a vacuum package with high pressure of 600 $800 \mathrm{MPa}$ for 300 seconds on the microbiological indicators of fish, quality and safety during storage. There are not detected oxidative processes and changes organoleptic parameters $(p<0.05)$ which is confirmed by the results of experiments Gudbjornsdottir, Jonsson, Hafsteinsson, et al. [24].

We also cannot ignore the results of study [25], which states that a lower oxidation of lipids under the influence of pressure of 100, 150 and 200 MPa when fish are displaced compared to ordinary submersible defrosting with water. Color changed obviously at $\geq 150 \mathrm{MPa}$, resulting in a cooked appearance. Samples thawed with HP showed better texture quality and lower lipid oxidation. Moreover, the oxidation of myofibrillar protein was significantly decreased at $100 \mathrm{MPa}$. It may be concluded, that high pressure without thermal treatment can be a potential alternative to produce high-quality thawed fish.

Processing meat with high-pressure and placing it in a vacuum packaging causes the inactivation of microbial cells, prevents the breakdown of protein and helps to inhibit the processes of oxidation of lipid components $[14 ; 17]$. The use of experimental hydrostat for treating chilled fish and meat with ultrahigh pressure without thermal treatment prevents the microbiological deterioration of food, preserves the nutritional value and hence increases the shelf-life.

It should be noted that in the control samples of the fish muscle tissue and skin, bacteria of the genus Achromobacter and Pseudomonas were detected throughout the entire period, the proportion of bacteria of the genus Pseudomonas was $87 \%$ of the total number of bacteria detected. This result is consistent with Blázquez, Burgos et al. research [16] which isolated Acinetobacter, Pseudomonas n Shewanella in plastic films with thymol and enterocin AS-48 and high-hydrostatic pressure (HP) treatment under refrigerated storage for 10 days.

According to our results all the samples of meat HHP treated samples ( $800 \mathrm{MPa}$ for $5 \mathrm{~min}$.) examined after 10 days of storage had the microbiological indicators which meet the requirements for fresh food products. HHP processing meat maintains high organoleptic characteristics of the product, causes the death of microbial cells, prevents the breakdown of protein and helps to weaken the oxidation processes of lipid components, which is consistent with the research Zhang, Wang and Zeng [11] which defined that sterilization and organoleptic characteristics depend on pressure, time of pressure and temperature used. It should be noted that the samples of meat from the control group were noted by greater microbial content. This result corresponds to the research of Merialdi, Ramini, Ravanetti [20]. 
It should be noted that under the action of pressure there is an activation of bilirubin in meat, which has extremely high antioxidant activity, one molecule of which can break more than two oxidation chains due to the formation of transmutation products, which, in turn, also have inhibitory properties which is consistent with [17].

Nevertheless, our experimental research of meat and fish allow to conclude that the HHP treatment did not adversely affect the organoleptic indicators of experimental samples as well as AOA and protein oxidation. Olatunde and Benjakul have other results [12]. According with them the organoleptic characteristic of HHP-treated food can be worsened. They also showed that fish treated with a pressure of more than $200 \mathrm{MPa}$ has the appearance of a boiled product, and also oxidative processes are enhanced in it. We suppose that the reason of these differences is thermal treatment.

Thus, the treatment with ultrahigh pressure of chilled fish and meat prevents the development of microbiological deterioration of food data, preserves the nutritional value and, accordingly, increases the shelf life. But at the same time, when processing by pressure of food products, it is necessary to control oxidative processes, as well as to determine the pressure applied to the product, taking into account the time and temperature of processing. We suppose, that the results of studies of the shelf life of perishable food products in vacuum packaging after high pressure treatment can be taken into account in food industry.

\section{Bibliography}

1. Ahn, J.; Balasubramaniam, V.M.; Yousef, A.E. Inactivation kinetics of selected aerobic and anaerobic bacterial spores by pressure-assisted thermal processing. Int. J. of Food Microbiol. 2007. No. 113(3). Pp. 321-329.

2. Margosch, D.; Ehrmann, M.A.; Buckow, R., et al. High-Pressure-Mediated Survival of Clostridium Botulinum and Bacillus Amyloliqvefaciens Endospores at High Temperature. Applied and Environ. Microbiol. 2006, 72(5). Pp. 3476-3481.

3. Matser, A.M.; Krebbers, B.; Berg, R.W. et al. Advantages of High Pressure Sterilisation on Quality of Food Products. Trends in Food Sci. and Technol. 2004, 15(2). Pp. 79-85.

4. Patterson, M.F. Microbiology of Pressure-Treated Foods. A Review. J. Applied Microbiol. 2005, 98(6). Pp. 1400-1409.

5. Blázquez, I.O.; Burgos, M.J.G.; Pérez-Pulido, R. et al. Treatment with High-Hydrostatic Pressure, Activated Film Packaging with Thymol Plus Enterocin AS-48, and Its Combination Modify the Bacterial Communities of Refrigerated Sea Bream (Sparus aurata) Fillets. Frontiers in Microbiology 2018, Vol. 9: 314. Pp. 1-10.

6. Heremans, K. High Pressure Effects on Proteins and Other Biomolecules. Annual Reviews of Biophysics and Bioengineering. 1982. V. 11. Pp. 1-21.

7. Popelka, P.; Nagy, J.; Pipová, M.; et al. Comparison of Chemical, Microbiological and Histological Changes in Fresh, Frozen and Dou ble Frozen Rainbow Trout (Oncorhynchus Mykiss). Acta Veterinaria (Brno). 2014, 83. Pp. 157-161.

8. Rastogi, N. K.; Raghavarao, K. S. Opportunities and Challenges in High Pressure Processing of Foods. Taylor \& Francis Group. 2010. Pp. 69-112.

9. Vinnikova, L. G.; Prokopenko, I. A. Primenenie Vysokogo Davleniia v Kachestve Alternativy Teplovoi Obrabotki Miasa Ptitsy [Application of High Pressure as an Alternative to Heat Treatment of Poultry Meat]. Vostochno-Evropeiskii Zhurnal Peredovykh Tekhnologii. 2015. No. 10(75). Pp. 31-36.

10. Caballero, L.; Mateos, P.; Borderias, J.A. at el. Extension of the Shelf Life of Prawns (Penaeus Japonicus) by Vacuum Packaging and High-Pressure Treatment. J. Fd Prot . 2000, 63(10). Pp. 1381.

\section{Библиографический список}

1. Ahn, J.; Balasubramaniam, V.M.; Yousef, A.E. Inactivation kinetics of selected aerobic and anaerobic bacterial spores by pressure-assisted thermal processing. Int. J. of Food Microbiol. 2007. No. 113(3). Pp. 321-329.

2. Margosch, D.; Ehrmann, M.A.; Buckow, R., et al. High-Pressure-Mediated Survival of Clostridium Botulinum and Bacillus Amyloliquefaciens Endospores at High Temperature. Applied and Environ. Microbiol. 2006, 72(5). Pp. 3476-3481.

3. Matser, A.M.; Krebbers, B.; Berg, R.W. et al. Advantages of High Pressure Sterilisation on Quality of Food Products. Trends in Food Sci. and Technol. 2004, 15(2). Pp. 79-85.

4. Patterson, M.F. Microbiology of Pressure-Treated Foods. A Review. J. Applied Microbiol. 2005, 98(6). Pp. 1400-1409.

5. Blázquez, I.0.; Burgos, M.J.G.; Pérez-Pulido, R. et al. Treatment with High-Hydrostatic Pressure, Activated Film Packaging with Thymol Plus Enterocin AS-48, and Its Combination Modify the Bacterial Communities of Refrigerated Sea Bream (Sparus aurata) Fillets. Frontiers in Microbiology 2018, Vol. 9: 314. Pp. 1-10.

6. Heremans, K. High Pressure Effects on Proteins and Other Biomolecules. Annual Reviews of Biophysics and Bioengineering. 1982. V. 11. Pp. 1-21.

7. Popelka, P.; Nagy, J.; Pipová, M.; et al. Comparison of Chemical, Microbiological and Histological Changes in Fresh, Frozen and Double Frozen Rainbow Trout (Oncorhynchus Mykiss). Acta Veterinaria (Brno). 2014, 83. Pp. 157-161.

8. Rastogi, N. K.; Raghavarao, K. S. Opportunities and Challenges in High Pressure Processing of Foods. Taylor \& Francis Group. 2010. Pp. 69-112.

9. Винникова Л.Г., Прокопенко И.А. Применение высокого давления в качестве альтернативы тепловой обработки мяса птицы // Восточно-Европейский журнал передовых технологий. 2015. № 10(75). C. 31-36.

10. Caballero, L.; Mateos, P.; Borderias, J.A. at el. Extension of the Shelf Life of Prawns (Penaeus Japonicus) by Vacuum Packaging and High-Pressure Treatment. J. Fd Prot . 2000, 63(10). Pp. 1381. 
11. Zhang, Zh.-H.; Wang, L.-H.; Zeng, X.-A.; et al. Non-Thermal Technologies and Its Current and Future Application in the Food Industry: A Review. International Journal of Food Science \& Technology. 2018. Vol. 54. Issue 1-13.

12. Olatunde, 0.0.; Benjakul, S. Nonthermal Process for Shelf-Life Extension of Seafoods : A Revisit. Comprehensive Reviews in Food Science and Food Safety. 2018. 10 May. Pp. 896-897.

13. Berkel, B.M.; Boogaard, B.V.; Heijnen, C. Preservation of Fish and Meat. Wageningen, The Netherlands: Agromisa Foundation, 2004. Pp. 125-133.

14. Jung, S.; Ghoul de Lamballerie-Anton, M., M. Influence of High Pressure on the Color and Microbial Quality of Beef Meat. Lebensmittel-Wissenschaft \& Technologie. 2003, 36(6). Pp. 625-631.

15. Han, J. M.; Ledward, D. A. High Pressure/Thermal Treatment Effects on the Texture of Beef Muscle. Meat Science. 2004, 68(3). Pp. 347-355.

16. Bai, Y.; Zhao, Y. Changes of Microscopic Structure and Shear Force Value of Bovine and Mutton Skeletal Muscle under Hydrostatic High-Pressure (HHP) Treatment. Fd. Sci. China. 2004. Vol. 25(9). Pp. 27-31.

17. Qin, H.; Nan, Q. X.; Che, R.Z. Effects of High Pressure on the Activity of Major Enzymes in Beef. Meat Research. 2001, 3. Pp. 13-16.

18. Argyri, A.A.; Papadopoulou, O.S.; Nisiotou, A. et al. Effect of High Pressure Processing on the Survival of Salmonella Enteritidis and Shelf-Life of Chicken Fillets. Food Microbiology 2018, Vol. 70. Pp. 55-64.

19. Huang, Ch.-Y.; Shiowshuh, Sh.; Sommers, Ch. et al. Modeling the Survival of Escherichia Coli 0157:H7 Under Hydrostatic Pressure, Process Temperature, Time and Allyl Isothiocyanate Stresses in Ground Chicken Meat. Front. Microbiol. 2018. 14 Aug.

20. Merialdi, G.; Ramini, M.; Ravanetti, E.; et al. Reduction of Listeria Innocua Contamination in Vacuum-Packaged Dry-Cured Italian Pork Products after High Hydrostatic Pressure Treatment. Italian Journal of Food Safety. 2015. Pp. 101-103.

21. Kudryashov, L.S.; Lisitsyn, A.B.; Tikhonov, S.L. Obrabotka Okhlazhdennogo Miasa Vysokim Davleniem i Sroki Khraneniia [Processing of Chilled Meat by High Pressure and Shelf Life]. Miasnaia Industriia. 2016. No. 2. Pp. 37-40.

22. Zakrys, P.I.; Hocan, S.A. Effects of Oxygen Concentration on Sensory Evaluation and Quality Indicators of Beef Muscle Packed under Modified Atmosphere. Meat Science. 2008. Vol. 79. Pp. 648-655.

23. Zakrys, P.I.; Sullivian, M.G. Investigation of High Oxygen Modified Atmosphere Packaging Effects on Protein Oxidation of Bovine M. Longissimus Dorsi Muscle During Chill Ed Strorage. Food Chemistry. 2011. Pp. 125-130.

24. Gudbjornsdottir, B.; Jonsson, A.; Hafsteinsson, H.; et al. Effect of High-Pressure Processing on Listeria Spp. and on the Textural and Microstructural Properties of Cold Smoked Salmon. LWT-Food Science and Technology. 2010. Vol. 43. Pp. 366-374.

25. Cui, Y.; Xuan, X.; Ling, J.; et al. Effects of High Hydrostatic Pressure-Assisted Thawing on the Physicochemical Characteristics of Silver Pomfret (Pampus Argenteus). Food Sci Nutr. 2019. Pp. 1-11.
11. Zhang, Zh.-H.; Wang, L.-H.; Zeng, X.-A.; et al. Non-Thermal Technologies and Its Current and Future Application in the Food Industry: A Review. International Journal of Food Science \& Technology. 2018. Vol. 54. Issue 1-13.

12. Olatunde, 0.0.; Benjakul, S. Nonthermal Process for Shelf-Life Extension of Seafoods : A Revisit. Comprehensive Reviews in Food Science and Food Safety. 2018. 10 May. Pp. 896-897.

13. Berkel, B.M.; Boogaard, B.V.; Heijnen, C. Preservation of Fish and Meat. Wageningen, The Netherlands: Agromisa Foundation, 2004. Pp. 125-133.

14. Jung, S.; Ghoul de Lamballerie-Anton, M., M. Influence of High Pressure on the Color and Microbial Quality of Beef Meat. Lebensmittel-Wissenschaft \& Technologie. 2003, 36(6). Pp. 625-631.

15. Han, J. M.; Ledward, D. A. High Pressure/Thermal Treatment Effects on the Texture of Beef Muscle. Meat Science. 2004, 68(3). Pp. 347-355.

16. Bai, Y.; Zhao, Y. Changes of Microscopic Structure and Shear Force Value of Bovine and Mutton Skeletal Muscle under Hydrostatic High-Pressure (HHP) Treatment. Fd. Sci. China. 2004. Vol. 25(9). Pp. 27-31.

17. Qin, H.; Nan, Q. X.; Che, R.Z. Effects of High Pressure on the Activity of Major Enzymes in Beef. Meat Research. 2001, 3. Pp. 13-16.

18. Argyri, A.A.; Papadopoulou, O.S.; Nisiotou, A. et al. Effect of High Pressure Processing on the Survival of Salmonella Enteritidis and Shelf-Life of Chicken Fillets. Food Microbiology 2018, Vol. 70. Pp. 55-64.

19. Huang, Ch.-Y.; Shiowshuh, Sh.; Sommers, Ch. et al. Modeling the Survival of Escherichia Coli 0157:H7 Under Hydrostatic Pressure, Process Temperature, Time and Allyl Isothiocyanate Stresses in Ground Chicken Meat. Front. Microbiol. 2018. 14 Aug.

20. Merialdi, G.; Ramini, M.; Ravanetti, E.; et al. Reduction of Listeria Innocua Contamination in Vacuum-Packaged Dry-Cured Italian Pork Products after High Hydrostatic Pressure Treatment. Italian Journal of Food Safety. 2015. Pp. 101-103.

21. Кудряшов Л.С., Лисицын А.Б., Тихонов С.Л. 06работка охлажденного мяса высоким давлением и сроки хранения // Мясная индустрия. 2016. № 2. С. 37-40.

22. Zakrys, P.I.; Hocan, S.A. Effects of Oxygen Concentration on Sensory Evaluation and Quality Indicators of Beef Muscle Packed under Modified Atmosphere. Meat Science. 2008. Vol. 79. Pp. 648-655.

23. Zakrys, P.I.; Sullivian, M.G. Investigation of High Oxygen Modified Atmosphere Packaging Effects on Protein Oxidation of Bovine M. Longissimus Dorsi Muscle During Chill Ed Strorage. Food Chemistry. 2011. Pp. 125-130.

24. Gudbjornsdottir, B.; Jonsson, A.; Hafsteinsson, H.; et al. Effect of High-Pressure Processing on Listeria Spp. and on the Textural and Microstructural Properties of Cold Smoked Salmon. LWT-Food Science and Technology. 2010. Vol. 43. Pp. 366-374.

25. Cui, Y.; Xuan, X.; Ling, J.; et al. Effects of High Hydrostatic Pressure-Assisted Thawing on the Physicochemical Characteristics of Silver Pomfret (Pampus Argenteus). Food Sci Nutr. 2019. Pp. 1-11. 


\section{Информация 06 авторах / Information about Authors}

\section{Diachkova,}

\section{Anna Victorovna}

\section{Дьячкова}

Анна Викторовна

тел./Phone: +7 (343) 221-27-66 E-mail: a.v.diachkova@urfu.ru

\section{Tikhonova,} Natalya Valeryevna

\section{Тихонова}

Наталья Валерьевна

тел./Phone: +7 (343) 221-27-66

E-mail: tihonov75@bk.ru
Candidate of Economic Science, Associate Professor, Associate Professor of the Food Engineering Department

620144, Russian Federation, Ekaterinburg, 8 March St. / Narodnoy Voli St., 62/45

Кандидат экономических наук, доцент, доцент кафедры пищевой инженерии Уральский государственный экономический университет 620144, Российская Федерация, г. Екатеринбург, ул. 8 Марта/Народной Воли, 62/45

Doctor of Technical Science, Professor, Professor of the Food Engineering Department Ural State University of Economics

620144, Russian Federation, Ekaterinburg, 8 March St. / Narodnoy Voli St., 62/45

Доктор технических наук, дочент, профессор кафедры пищевой инженерии Уральский государственный экономический университет 620144, Российская Федерация, г. Екатеринбург, ул. 8 Марта/Народной Воли, 62/45 ORCID: https://orcid.org/0000-0001-5841-1791 